\title{
Facebook vs. Paper-and-Pencil Writing: Comparing Japanese EFL Students' Opinions of the Writing Mediums
}

\section{Gilbert Dizon}

\section{Himeji Dokkyo University}

\begin{abstract}
Although current literature indicates that L2 students have mostly favorable attitudes towards Facebook, no study has incorporated a control group to examine learners' views of the social-networking service (SNS). Thus, it is unknown if L2 students view the SNS more positively than other writing mediums. This study seeks to fill this gap by analyzing the views of Japanese university EFL students. The learners were divided into two groups: one which used Facebook for writing tasks $(n=16)$ and another which used paper-and-pencil $(n=14)$. A nine-item Likert-scale questionnaire was administered to assess the students' opinions towards the writing mediums. The results revealed that the Facebook group had more favorable opinions towards eight of the survey statements. Interestingly, however, the learners in the paper-and-pencil group preferred their writing medium to a greater degree. These findings highlight the mixed opinions L2 students can have towards Facebook despite its perceived benefits.
\end{abstract}

先行研究では、第2 言語 (L2) 学習者がFacebookについて概ね好意 的な捉え方をしていると示されている。しかし、ソーシャル・ネットワーキ ング・サービス (SNS) に対する学習者の意識調査で、対照群を設定した 調査研究は行われていない。それゆえ、L2学習者がSNSを他のライテイン グ手段よりも好ましいと考えているかどうかは明らかでない。そこで本論 は、EFL学習者である日本人大学生の意識を調査・分析し、先行研究の不 足を補うことを目的としている。本論では、学習者を2つのグループに分 け、1つはFacebookを用いたライティングを行うグループ (16名)、もう1つ は筆記用具を用いるグループ (14名) とした。これら2つのグループに、リ ッカート尺度による9項目のアンケート調査を実施し、それぞれのライティ ング手段に対する学習者の意識を調査した。その結果、Facebookを使用 したグループは、調査項目のうち8項目において、筆記用具を使用したグ ループよりも、より好意的な意見を持っていることが明らかになった。し かし興味深いことに、自分が利用したライテイング手段のほうが好ましい という認識は、Facebookを利用したグループよりも筆記用具を利用した グループのほうが高かった。これらの調査結果は、Facebookにさまざま な利点が認められるものの、L2学習者にはFacebookに対して多様な受け 止め方がありうるということを示している。

W ith over 1.1 billion active users each day, Facebook (FB) is the most widely used SNS in the world (Facebook, 2016). Given the ubiquity and importance of FB among students (Blatther \& Fiori, 2009; Godwin-Jones, 2010), language researchers have investigated L2 learners' attitudes towards the use of the SNS for learning in the L2 classroom and have found that they have generally positive opinions (Kabilan, Ahmad, \& Abidin, 2010; Shih, 2011; Wang \& Kim, 2014). Even among learners in Japan, there seems to be favorable views towards FB (Dizon, 2015). However, none of these studies involved a control group; thus, it is not known if $\mathrm{L} 2$ students view writing via FB more positively than paper-and-pencil (PP) writing. Therefore, this paper aims to fill this gap by examining the opinions of two groups of Japanese EFL students: one which used FB writing over the course of a semester and another which wrote via PP.

\section{Background}

FB offers several distinct advantages in the eyes of L2 learners. The Taiwanese EFL students in Shih's (2011) research thought that the SNS enhanced cooperative learning as well as reduced anxiety communicating in the target language. Lower levels of anxiety were also reported as a benefit of FB writing by the L2 Chinese learners in a study by Wang and Kim (2014). The students also stated that writing through the SNS helped increase their confidence in the $\mathrm{L} 2$ and allowed them to engage in authentic communication. Similarly, the L2 English learners in Kabilan et al.s (2010) study had favorable views of FB, with a majority of the participants agreeing that the SNS enhanced motivation and confidence in the target language and afforded them additional opportunities to improve their writing skills. Lastly in the context of Japan, Dizon (2015) found three perceived advantages of FB among the Japanese EFL learners: a lowstress environment, ease of use, and convenience.

Although there have been mixed results regarding the SNS's ability to promote improvements in the quality of L2 students' writing (Dizon, 2016; Wang \& Vásquez, 2014), Shih (2011) found that FB could indeed enhance the academic writing skills of $\mathrm{L} 2$ learners. A total of twenty-three 1st-year English majors at a university in Taiwan participated in the study which involved a combination of FB writing and peer assessment. The students were divided into six groups and were instructed to post on their 
respective FB pages and comment on others' posts. According to the results of pre- and post-tests based on the National College Entrance Examination, Shih (2011) determined that FB and peer assessment led to improvements in writing organization, content, spelling, and vocabulary. Notably, the group that made the greatest improvement was the lowscore group, suggesting that beginners may have the most to gain from using FB.

Despite the benefits that FB offers, not all L2 learners are comfortable with using it for language learning and/or do not perceive it to be useful in this regard. Alm (2015) studied the opinions of language learners at a university in New Zealand and discovered that attitudes were moderate at best. While advanced language students viewed FB as somewhat useful for informal language learning, beginner and intermediate students had less favorable perceptions. Moreover, these students were less likely to interact with others via the SNS in their L2, primarily because they lacked FB friends who spoke the target language. The two L2 English learners in Chen's (2013) case study of FB also had mixed views of the SNS. Although one of the participants actively engaged with native speakers of the L2 through the site, the other student "felt marginalized and uncomfortable" (p. 154). Additionally, the learner expressed a desire to take a break from English studies when she used FB, and instead used the site to connect with her L1 friends. In other words, the learner used the site for leisure purposes rather than to actively improve her L2. This emphasis on leisure may be a reason why all of the learners in Wang and Kim's study (2014) stated that FB had the potential to easily distract them from their academic studies. Given this, it may be necessary to advise L2 students on how to effectively leverage FB for language learning purposes. To sum up, L2 students have mostly favorable views towards FB, with the primary advantages being increased confidence, enhanced motivation and reduced levels of anxiety. In addition, the SNS offers language students more chances to use the L2 outside of the classroom in a meaningful way. However, there are a few downsides as well, namely, FB may be intimidating to some students who lack the proficiency to communicate with others, particularly native speakers, and the site may serve as a distraction for language learners. While the aforementioned research provides insight into the views $\mathrm{L} 2$ students have towards FB as well as its potential to foster writing improvements, it is still unknown if learners view writing via the SNS more positively than a different writing medium. Thus, the aim of this study was to evaluate Japanese students' opinions of FB and a traditional writing medium. Specifically, the following research question was addressed in this paper: What are Japanese EFL learners' opinions of Facebook and paper-and-pencil writing?

\section{Methodology}

\section{Participants}

A total of 30 Japanese EFL students at a private Japanese university agreed to participate in the study via written informed consent. The participants were selected using convenience sampling. All of the students were enrolled in an elective course entitled Communicative English, which met three times a week in 90-minute classes during the 2016 spring semester. The course focused on the four skills of listening, reading, speaking, and writing, with a particular emphasis on output. Sixteen of the learners were placed in the FB group and were taught by the researcher. This was done due to the fact that these learners had desktop computers in their classroom, and thus had the ability to write with FB during class. The remaining 14 students were taught by two other English instructors in two separate classes and were placed in the PP group.

Three writing assessments were administered at the start, middle, and end of the treatment to measure the writing abilities of the participants in three specific areas: writing output (number of words written), lexical richness (the ratio of words written which were beyond the 1000 most frequent words and the total number of words produced), and grammatical accuracy (the number of treatable errors produced per 100 words on each writing assessment). All three assessments followed the same procedure as the treatment. Moreover, the writing topics were the same for both groups (pretest: Golden Week plans; mid-test: university life; post-test: summer vacation plans). Non-parametric statistical tests showed that there were no significant differences between the dependent variables of the learners in the PP group and those in the FB group at the outset of the treatment. While the focus of this paper is on the students' opinions of the two writing mediums, full quantitative results can be found in a separate article (see Dizon, 2016).

\section{Treatment}

The participants completed two timed guided freewritings each week for a total of 12 weeks. The students in the FB group wrote on their respective FB pages while those in the PP group wrote in individual journals. Hwang (2010) found that freewriting could enhance the writing fluency of EFL 
learners; thus, this was designated as the primary writing task in all the classes involved in the study. Each freewriting lasted 10 minutes and the students were not allowed to use a dictionary or any other form of writing aid. The use of browser spellcheck was not monitored during FB writing, however, due to the fact that this is an inherent advantage of computer-mediated writing. Topics were selected by the individual teachers of each class (Appendix A). Although the students' writing was not graded, the learners in both groups were given corrective feedback by the researcher in order to promote grammatical accuracy. To make the corrective feedback more focused, only "treatable errors," that is, errors that "occur in a patterned, rule-governed way," (Ferris, 1999, p. 6) were marked. Writing on FB was marked with the comment function while any errors made with PP were marked directly with red pen. Before starting a new writing task, the students were required to review and correct any grammar mistakes they made during the previous freewriting activity.

\section{Use of Facebook in the Study}

The learners who used Facebook were divided into two FB groups based on their classes. Each Facebook group was set to secret; thus, only the researcher and the class members could view and respond to posts. This was done to protect the privacy of the students as all but one of them used their personal FB accounts. This was not mandatory however; students were given the option of using their own account or creating a new one specifically for the class. After the completion of each freewriting, the students in the FB group were assigned to comment on at least two other posts as homework. This was the only difference in the writing procedures between those in the FB group and the PP group, and could not have been implemented in the PP group due to the fact that the students' journals were collected after class for correction.

\section{Research Instrument}

Qualitative data for this study were collected via an L1 questionnaire which was developed by the researcher in English and translated into the students' native language by a Japanese colleague (Appendix B). The survey was administered in class during the final week of the semester. The students who used FB completed it online through SurveyMonkey while those who wrote with PP filled it out by hand. The questionnaire asked the participants to rate their level of agreement towards nine statements based on a five-point Likert scale ranging from strongly disagree to strongly agree. The first four items on the survey focused on affective factors related to the writing task. Items five through eight centered on the linguistics improvements the learners could make through each writing medium. The final item examined the students' preference towards FB or PP.

\section{Results and Discussion}

As shown in Table 1, the FB group had higher levels of agreement towards eight out of the nine survey statements. In particular, items three, six, seven, and eight were viewed favorably by those in the FB group, with at least $24 \%$ more participants agreeing or strongly agreeing with the statements compared to those in the PP group. These results confirm that increased confidence is one of the main benefits of incorporating FB in L2 writing (Kabilan et al., 2010; Wang \& Kim, 2014). While PP writing activities usually revolve around the teacher as the sole or primary reader of students' writings, FB writing involves multiple readers, including the fellow members of a FB group or possibly the general public. Given this, students may develop more confidence in their L2 writing abilities through SNSs because they are writing for a larger audience.

The results also reinforce the argument that the FB approach can enhance L2 writing skills, at least from the perspective of EFL learners (Kabilan et al., 2010; Shih, 2011). This is in contrast to those who believe that the usage of SNSs and other Web 2.0 technologies are not appropriate in academic contexts (Lohnes \& Kinzer, 2007; Waycott, Bennett, Kennedy, Dalgarno, \& Gray, 2010). Like any other form of writing, what matters most is not the medium itself, but rather how learners are directed towards the writing task. Learners must be given opportunities to write for a variety of purposes that are meaningful to their own lives and futures, regardless of whether or not this writing occurs in a digital environment or with paper-and-pencil.

One surprising finding is that the students in the FB group perceived the corrective feedback to be more easily understandable than those in the PP group. This is despite the fact that teachers cannot directly mark students' writing or posts with FB. While FB and other web 2.0 technologies were not originally made for formal, language learning purposes, teachers can leverage their features to help students improve their language skills in the target language. What is key is to incorporate FB in ways that are pedagogically sound while also providing clear instructions on how to complete and excel in the given task. 
Table 1. Percentage of Agreement Towards Questionnaire Statements

\begin{tabular}{|c|c|c|c|}
\hline \multirow[b]{2}{*}{$\#$} & \multirow[b]{2}{*}{ Statement } & \multicolumn{2}{|c|}{ Group } \\
\hline & & PP & $\mathrm{FB}$ \\
\hline 1 & $\begin{array}{l}\text { I was motived to learn En- } \\
\text { glish through freewriting. }\end{array}$ & $71.4 \%$ & $81.3 \%$ \\
\hline 2 & $\begin{array}{l}\text { I enjoyed freewriting in } \\
\text { English. }\end{array}$ & $71.4 \%$ & $81.3 \%$ \\
\hline 3 & $\begin{array}{l}\text { I am more confident in } \\
\text { English writing because of } \\
\text { freewriting. }\end{array}$ & $57.1 \%$ & $81.3 \%$ \\
\hline 4 & $\begin{array}{l}\text { My attitude towards learning } \\
\text { English became more serious } \\
\text { because of freewriting. }\end{array}$ & $42.9 \%$ & $62.5 \%$ \\
\hline 5 & $\begin{array}{l}\text { I was able to improve my } \\
\text { English grammar through } \\
\text { freewriting. }\end{array}$ & $64.3 \%$ & $68.8 \%$ \\
\hline 6 & $\begin{array}{l}\text { I was able to write English } \\
\text { more fluently through free- } \\
\text { writing. }\end{array}$ & $35.7 \%$ & $81.3 \%$ \\
\hline 7 & $\begin{array}{l}\text { I was able to improve my } \\
\text { English writing skills through } \\
\text { freewriting. }\end{array}$ & $50.0 \%$ & $93.8 \%$ \\
\hline 8 & $\begin{array}{l}\text { I was able to easily under- } \\
\text { stand the grammar correc- } \\
\text { tions. }\end{array}$ & $64.3 \%$ & $93.8 \%$ \\
\hline 9 & $\begin{array}{l}\text { I prefer English writing } \\
\text { with pencil-and-paper to } \\
\text { writing with Facebook. / I } \\
\text { prefer English writing with } \\
\text { Facebook to writing with } \\
\text { paper-and-pencil. }\end{array}$ & $64.3 \%$ & $62.5 \%$ \\
\hline
\end{tabular}

Although the FB group held more positive views towards freewriting, it is interesting to find that the PP group preferred their writing medium to a higher degree than those who wrote on the SNS (64.3\% to $62.5 \%)$. While this may seem counterintuitive, it does make sense given the fact that the Japanese education system largely revolves around paper-and-pencil writing rather than the use of computers (Sekine, 2015). Therefore, learners in Japan may feel more comfortable writing with PP than using FB due to their familiarity with the former.

In short, the participants in the FB group had more favorable opinions towards freewriting with the SNS than those in the PP group. In particular, increased confidence, greater writing fluency, improved writing skills, and more easily understand- able grammar corrections were seen as the main benefits of freewriting through FB. While these advantages do not guarantee that learners will make concrete L2 gains through the use of FB, it does show that it has the potential to support language learning due to the positive attitudes that students have towards the SNS. Attitudes towards a writing medium are significant, as Ajzen and Fishbein (1980) argued in their theory of reasoned action which posits that attitude can directly impact behavior, that is, learner performance on a given task. Therefore, language teachers must choose activities that are seen as useful in the eyes of their students in order to maximize the improvements that they can make in an L2.

\section{Conclusion}

As the use of SNSs in L2 classrooms becomes more widespread, so does the need to investigate learners' perceptions towards their usefulness in formal language teaching and learning. Accordingly, the goal of this study was to determine the attitudes that Japanese EFL learners had towards FB and PP writing. Although the participants in the PP group did in fact prefer the writing medium to a slightly greater degree than those in the FB group (64.3\% to $62.5 \%)$, the FB group had higher levels of agreement on all the other items on the survey. This paints a somewhat unclear picture of Japanese students' views towards the SNS. Therefore, more research needs to be done in order to gain a better understanding of the opinions that Japanese EFL learners have regarding FB.

This study has several limitations that need to be pointed out. One is the small sample size. As a result, future studies should incorporate larger groups of students chosen randomly among a population. Additionally, the participants in the PP group did not have the opportunity to write with FB or comment on the writing of others during the study. Therefore, the students' freewriting experiences were not identical and this could have impacted the results. Given this, it would be worthwhile to employ a study where two groups write via FB and PP for an equal amount of time and afterward survey their opinions to see which medium they prefer. The differing freewriting topics in each group could have also influenced the participants' opinions of the writing mediums; namely, the writing topics in the FB group could have better connected with the students, leading them to view the medium more positively. Lastly, the participants' responses to survey items one through seven may reflect their views of freewriting rather than the writing mediums themselves. Thus, future research ought to differentiate between these variables (writ- 
ing task and medium) in order to better understand the relationship between the two and how they impact student perceptions.

\section{References}

Alm, A. (2015). Facebook for informal language learning. EUROCALL Review, 23(2), 3-18. Retrieved from http://polipapers.upv.es/index.php/eurocall/article/ view/4665/4791

Ajzen, I., \& Fishbein, M. (1980). Understanding attitudes and predicting social behavior. Englewood Cliffs, NJ: Prentice-Hall.

Blattner, G. \& Fiori, M. (2009). Facebook in the language classroom: Promises and possibilities. International Journal of Instructional Technology and Distance Learning, 6(1), 17-28, Retrieved from http://www.itdl.org/ journal/jan_09/article02.htm

Chen, H.-I. (2013). Identity practices of multilingual writers in social networking spaces. Language Learning \& Technology, 17(2), 143-170. Retrieved from http://llt. msu.edu/issues/june2013/chen.pdf

Dizon, G. (2015). Japanese students' attitudes towards the use of Facebook in the EFL classroom. The Language Teacher, 39(5), 9-14.

Dizon, G. (2016). A comparative study of Facebook vs. paper-and-pencil writing to improve L2 writing skills. Computer Assisted Language Learning, 29(8), 1249-1258. doi: http://dx.doi.org/10.1080/09588221.2016.1266369

Facebook. (2016). Company info. Retrieved from http:// newsroom.fb.com/company-info/

Godwin-Jones, R. (2010). Emerging technologies: Literacies and technologies revisited. Language Learning \& Technology, 14(3), 2-9. Retrieved from http://llt.msu. edu/issues/october2010/emerging.pdf

Hwang, J. A. (2010). A case study of the influence of freewriting on writing fluency and confidence of EFL college-level students. Second Language Studies, 28(2), 97-134. Retrieved from http://www.hawaii.edu/sls/wpcontent/uploads/2014/09/Hwang.pdf

Kabilan, M. K., Ahmad, N., \& Abidin, M. J. Z. (2010). Facebook: An online environment for learning of English in institutions of higher education? Internet and Higher Education, 13, 179-187. doi: 10.1016/j.iheduc.2010.07.003

Lohnes, S., \& Kinzer, C. (2007). Questioning assumptions about students' expectations for technology in college classrooms. Innovate: Journal of Online Education, 3(5), 1-6. Retrieved from http://nsuworks.nova.edu/ innovate/vol3/iss5/2/

Sekine, Y. (2015, June 29). The future of ICT education in Japan. Retrieved from http://kipis.sfc.keio.ac.jp/thefuture-of-ict-education-in-japan/

Shih, R. C. (2011). Can Web 2.0 technology assist college students in learning English writing? Integrating Facebook and peer assessment with blended learning. Australasian Journal of Educational Technology, 27(5), 829845. Retrieved from https://eric.ed.gov/?id=EJ943540
Wang, S., \& Kim, D. (2014). Incorporating Facebook in an intermediate-level Chinese language course: A case study. IALLT Journal, 44(1), 38-78. Retrieved from http://old.iallt.org/iallt_journal/incorporating facebook_in_an_intermediate_level_chinese_ language_course_a_case_study

Wang, S., \& Vásquez, C. (2014). The effect of target language use in social media on intermediate-level Chinese language learners' writing performance. CALICO Journal, 31(1), p. 78-102. http://dx.doi.org/10.11139/ cj.28.2.345-368

Waycott, J., Bennett, S., Kennedy, G., Dalgarno, B., \& Gray, K. (2010). Digital divides? Student and staff perceptions of information and communication technologies. Computers \& Education, 54(4), 1202-1211. doi: http://dx.doi. org/10 .1016/j.compedu.2009.11.006

Gilbert Dizon is a lecturer at Himeji Dokkyo University, Japan. He holds an MA in Applied Linguistics from the University of Massachusetts Boston. His major research interests are focused on the use social networking sites and mobile apps to enhance L2 learning.

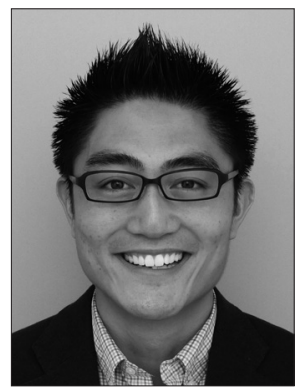

\section{Appendix A \\ Weekly Freewriting Topics}

\section{Paper-and-pencil Paper-and-pencil} group A group $\mathbf{B}$

Week 1 Junior high Favorite place/ school/Childhood Travel

Week 2 Travel preferenc- Cities vs. the es/Dream vacation

Week 3 Vacation plans/ English motivation

Week 4 My home/Movies New skill/Healthy living

Week 5 Self-improvement/Food

Week 6 Travel experiences/Recipe

Bad habits/Studying abroad

Things that annoy me/Things I do to relax

Week 7 Next vacation/Ad- Difficult experivice to past self ence/Life after graduation 


\begin{tabular}{|c|c|}
\hline Week 8 & $\begin{array}{l}\text { Travel advice/ } \\
\text { High school }\end{array}$ \\
\hline Week 9 & $\begin{array}{l}\text { University com- } \\
\text { plaints/English } \\
\text { teachers }\end{array}$ \\
\hline Week 10 & $\begin{array}{l}\text { Best friend/Tech- } \\
\text { nology }\end{array}$ \\
\hline Week 11 & $\begin{array}{l}\text { Internet/My } \\
\text { treasure }\end{array}$ \\
\hline Week 12 & $\begin{array}{l}\text { Favorite holiday/ } \\
\text { Ideal wedding }\end{array}$ \\
\hline & Facebook group A \\
\hline Week 1 & Jobs/Travel \\
\hline Week 2 & $\begin{array}{l}\text { Hometown/Fam- } \\
\text { ily }\end{array}$ \\
\hline Week 3 & $\begin{array}{l}\text { High school/Per- } \\
\text { sonality }\end{array}$ \\
\hline Week 4 & Movies/Home \\
\hline Week 5 & $\begin{array}{l}\text { English/Happi- } \\
\text { ness }\end{array}$ \\
\hline Week 6 & $\begin{array}{l}\text { Clothes/US } \\
\text { President visit to } \\
\text { Hiroshima }\end{array}$ \\
\hline
\end{tabular}

Week 7 Commute/Zoo incident

Week 8 Daily routine/ Music

Week 9 Internet/Shopping

Week 10 Hobbies/YouTube

Week 11 Dream vacation/ Skills

Week 12 Volunteer work/ Spring semester
Health/My diet

School clubs/

What if...

Success/Technology

Tests/Money vs. happiness

Health vs. happiness/New classes

\section{Facebook group B}

Role models/ Leaders

Stereotypes/Travel preferences

Domestic travel/ Japanese customs

Bad travel experiences/Part-time jobs

Future career/ Movies

Money \& happiness/War apologies

Zoo incident/Foreign languages

How to study a foreign language/ Internet safety

Favorite commercials/Shocking commercials

Aliens/Cosmetic surgery

Public vs. private schools/Single sex vs. mixed schools

Childhood education/Spring semester

\section{Appendix B}

Freewriting Survey

自由作文についてのアンケート調査

自由作文について、それぞれの文を読んで、あなたの 考えに一番当てはまるものを選んでください。ご協力よろ しくお願いします。

\begin{tabular}{|c|c|c|c|c|c|}
\hline & 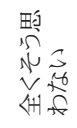 & 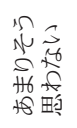 & 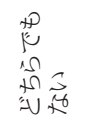 & 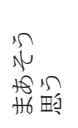 & 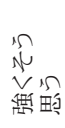 \\
\hline $\begin{array}{l}\text { 自由作文を通して、英 } \\
\text { 語の学習意欲がわい } \\
\text { た。 }\end{array}$ & 0 & 0 & 0 & 0 & 0 \\
\hline $\begin{array}{l}\text { 英語の自由作文は楽し } \\
\text { かった。 }\end{array}$ & $\bigcirc$ & 0 & 0 & 0 & 0 \\
\hline $\begin{array}{l}\text { 自由作文のおかげで、 } \\
\text { 英作文に対する自信が } \\
\text { 前よりもついた。 }\end{array}$ & $\bigcirc$ & 0 & 0 & 0 & 0 \\
\hline 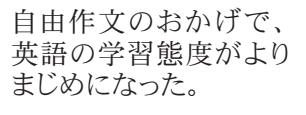 & $\bigcirc$ & 0 & $\bigcirc$ & 0 & 0 \\
\hline $\begin{array}{l}\text { 自由作文を通じて、英 } \\
\text { 語の文法力が向上 } \\
\text { た。 }\end{array}$ & 0 & 0 & 0 & 0 & 0 \\
\hline $\begin{array}{l}\text { 自由作文を通じて、英 } \\
\text { 語を前よりもスラスラと } \\
\text { 書けるようなった。 }\end{array}$ & $\bigcirc$ & 0 & 0 & 0 & 0 \\
\hline $\begin{array}{l}\text { 自由作文を通じて、英 } \\
\text { 作文の技術が向上 } \\
\text { た。 }\end{array}$ & $\bigcirc$ & 0 & 0 & 0 & 0 \\
\hline $\begin{array}{l}\text { 文法間違いの指摘が簡 } \\
\text { 単に理解できるようこ } \\
\text { なつた。 }\end{array}$ & $\bigcirc$ & 0 & 0 & 0 & 0 \\
\hline 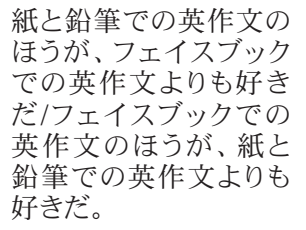 & 0 & 0 & $\bigcirc$ & 0 & 0 \\
\hline
\end{tabular}

\section{Try be a GREEN JALTER}

1. Return your conference badge

2. Remember the 4 R's

3. Bring your own toothbrush, chopsticks, notebook, pen, and water bottle

4. Eat a vegetarian meal

5. Think GREEN! 